\title{
PARÁdi Ákos \\ A Belga Nemzeti Csendőrség a XX. század második évtizedében
}

( doi: 10.31626/HU-EISSN2530094X.IITOM.69-82.p)

belga rendvédelmi modellre hagyományosan nagy hatást gyakorolt a francia rendvédelmi gyakorlat. A 1 Maréchaussée franciaországi elterjedése kapcsán a későbbi Belgium térségében is ez a rendfenntartó szervezet terjedt el. Franciaországban ugyan a „nagy francia forradalmat" közvetlenül megelőzően a Maréchassuée szervezetét átkeresztelték csendőrségre, ${ }^{1}$ erre a névváltoztatásra azonban Belgiumban csak 1830-ban került sor a testület jelentős átszervezésével egybekapcsolva. A XX. század első felében kialakított szabályozások szerint - kisebb-nagyobb módosításoktól eltekintve - müködött a Belga Nemzeti Csendörség a XX. század első felében is.

A belga csendőrség is — a hagyományos csendőrségi helyzetnek megfelelően — kettős alárendeltségben müködött. A személyi állomány tagjai — mivel a csendőrök személyükben katonának minősültek, lévén a belga csendőrség is katonailag szervezett örtestület ${ }^{2}$ - a belga hadügyminisztériumhoz tartoztak, a Belga Nemzeti Csendőrség mint testület felett pedig az igazságügyi tárca gyakorolt közvetlen felügyeltet. A Belga Nemzeti Csendőrség élén tábornok állt, aki a belga hadügyminiszter közvetlen alárendeltségébe tartozott. ${ }^{3}$

A $29405 \mathrm{~km}^{2}$ területű és — a vizsgált időszakban — 7619752 fő lakosságú Belga Királyságban 139 tiszt vezetésével 3609 gyalogos és 247 lovas csendőr teljesített szolgálatot, tehát az 5995 fönyi teljes személyi állomány 2,32\%-át alkották a tisztek. A csendőrségi testület parancsnoka szük létszámú törzskara által irányította a testületet. A Belga Királyságban egy csendőrre átlag $5 \mathrm{~km}^{2}$ terület és 1300 fő lakos jutott. Ugyanebben az időben a trianoni békediktátum által megcsonkított Magyar Királyságban — amelynek a Belga Királyságnál mintegy háromszor nagyobb területe volt — 12000 fó csendőr teljesített szolgálatot.

A csendőrségi testület parancsnokának az alárendeltségébe tartoztak a csoport-parancsnokságok. A Belga Királyság területén összesen 6 csoport-parancsnokság müködött. A csoport- 
parancsnokságok élén alezredes vagy örnagy állt. A csoportok 3 - állandó müködési területtel rendelkezö — századból álltak. A század-parancsnokságok alá - amelyek élén századosok álltak - mindenütt 3 kerület-parancsnokság tartozott. A kerület-parancsnokságok - amelyeket hadnagyok, vagy föhadnagyok vezettek - pedig 8-10 örsöt irányítottak. Az örsökön szolgálatot teljesítő csendőrök lét-száma általában 4-6 fö volt. ${ }^{5}$

Ez a szervezeti felépítés kísértetiesen hasonlított a Magyar Királyi Csendőrség struktúrájára, ahol a legkisebb szervezeti egység az örs volt. Az őrsök felett a Magyar Királyi Csendörség kötelékében is - az országos parancsnokság szerepét betöltő csendőr felügyelöséget figyelmen kívül hagyva - háromszintü parancsnoksági rendszer müködött, a szakasz-, a szárny- és a kerület-parancsnokság. Eredetileg a dualizmuskori Magyar Királyság időszakában a Magyar Királyi Csendőrség szervezete is 6 kerületből állt, mint ahogyan a Belga Királyság területén is 6 csendör csoport-parancsnokság müködött. A Magyar Királyi Csendőrség szervezetéből azonban a XX. század húszas éveiben még hiányoztak a mobil szervezeti elemek, azokat csak később - a II. világháború tapasztalatai alapján - alap-vetően az ellenséges diverziós csapatok felszámolása érdekében hozták létre karhatalmi zászlóalj for-májában. ${ }^{6}$

A Belga Királyságban azonban a Belga Nemzeti Csendőrség szervezetéhez úgynevezett központi és mobil alakulatok is tartoztak. A csendörségi testület parancsnokának a közvetlen alárendeltségében állt a raktár-parancsnokság, amely a testület ellátásáról gondoskodott és a mozgó légió.

A belga rendvédelmi modellben a mozgó légió hivatását alkotta az esetenként jelentősebb létszá-mot igénylő rendvédelmi teendők ellátása, elsősorban karhatalmi feladatok teljesítése. A mozgó légió alakulatai az ország bármely pontján bevethetőek voltak, az állomáshelyük pedig Bruxelles-ben volt. A mozgó légió szervezete 2 századcsoportból és 1 ágyús-golyószórós gépkocsizó csoportból állt. A századcsoportok egyegy lovas és egy-egy kerékpáros századból, a gépkocsizó csoport pedig egy ágyús és egy golyószórós szakaszból állt. A lo- 
vas századok 116 hátas és 6 hámos lóval valamint 4 kerékpárral, a kerékpáros századok pedig 122 kerékpárral, 3 hámos lóval, továbbá a lovas és a kerék-páros századok is századonként 1 gépkocsival és 1 konyhakocsival is rendelkeztek. Az ágyús szakasz 2 ágyús gépjármúböl, a golyószórós szakasz pedig 6 golyószórós gépkocsiból állt. Emellett pedig az ágyús és a golyószórós szakaszhoz is rendszeresítettek 1 tehergépkocsit. A századok személyi állománya századonként 127 főből, a gépkocsizó csoport létszáma pedig 62 főből állt.

A mozgó légió mellett a belga csendőrség csoport-parancsnokságai is rendelkeztek mozgó alakulatokkal, mégpedig csoport-parancsnokságonként egy-egy félszázaddal. A félszázadokat 2 szakaszba, lovas és golyószórós szakaszba szervezték. Minden félszázadban 100 lovas és 17 gyalogos csendőr teljesített szolgálatot. A golyószórós szakasz 3 golyószórós gépkocsiból állt. Emellett a félszázadok 1 gépkocsival és 1 konyhakocsival is fel voltak szerelve. A mozgó légió parancsnoki beosztása ezredesi, a század csoport-parancsnoki beosztás őrnagyi, a század-parancsnoki beosztás pedig hadnagyi hely volt. A csoport-parancsnokságok manőver tartalékát alkotó félszázadok parancsnokai századosok, a szakaszok parancsnokai pedig hadnagyok, vagy föhadnagyok voltak. ${ }^{7}$

A belga csendörség parancsnokának a közvetlen felügyelete alatt álló mozgó légióban és a 6 csoport-parancsnokság irányítása alatt álló félszázadokban összesen 1272 fő csendőr teljesített szolgálatot. A mozgó alakulatokban szolgálatot teljesítő csendőrök létszámát nyilvánvalóan le kell vonni a testület teljes személyi állományából a járőrtevékenységet folytató csendörök létszámának a kiszámításakor, még akkor is, ha a mozgó alakulatokban szolgálatot teljesítő csendőrök egy részét esetenként beosztották járőrszolgálati feladatok ellátására is. Az 5995 főnyi csendőri állományból ha levonjuk az 1272 fő mobil csendőrt, akkor összesen 4723 fö marad, amiből még a tiszti kar létszámát is levonva 4584 fó csendőr marad a rendszeres járőrszolgálat ellátására. Amennyiben figyelembe veszszük a betegségeket, szabadságokat stb., illetve az őrsökön az őrsügyeleti szolgálatokat ellátókat, akkor még ennél is szükebb létszámkeretet kapunk a csendőr járőr szolgálat tekinte- 
tében hadra fogható személyi állomány létszámát illetően. A belga csendőr őrsök létszámából fakadóan pedig egyértelmủen következik, hogy egy átlagos csendőr őrs egy napon egy legfeljebb kettő kétfős járőr vezénylésére volt alkalmas.

A belga csendőrség személyi állománya - a Magyar Királyi Csendőrséghez hasonlóan, a II. világháború során létesített karhatalmi alakulatok legénységét leszámítva — hivatásos csendőrökből állt. A Belga Nemzeti Csendőrséghez való felvétel követelményei szinte szó szerint megegyeztek a Magyar Királyi Csendőrségével:

„a) belga állampolgárság;

b) legalább 21 és legfeljebb 40 éves életkor;

c) legalább $168 \mathrm{~cm}$ testmagasság;

d) nőtlen, elvált, vagy gyermektelen özvegyi állapot;

e) testi alkalmasság;

f) helyesen írni vagy olvasni tudás franciául, flamandul, vagy németül;

g) a négy számtani alapmüvelet ismerete;

h) fedhetetlen erkölcsösség és magatartás;

i) az elöljáróknak teljes megelégedése mellett teljesített csapatszolgálat;

j) törvény által előírt katonai szolgálati idő letöltése. ${ }^{8}$

Abban az esetben azonban, ha a szükséges létszámot a kellő képzettséggel és képességekkel rendelkező személyekkel nem tudták betölteni, akkor megengedett volt az alacsonyabb termetü, a nős férfiak, illetve a háború alatt - anélkül, hogy katonai szolgálatra behívták volna - hazafiságukat bizonyító személyek, továbbá a testülettől kilépett, de felvételüket újra kérő volt csendőr altisztek, továbbá a haderöben harcos állományú beosztásban szolgálatot teljesítetők felvétele is. A belga csendőrséghez felvételüket kérők háromévenként 3 évre újíthatták meg a szolgálati viszonyukat a 20 . szolgálati évükig, ezt követően pedig 1, 2, 3, vagy 4 évre vállalhattak újabb szolgálatot. A testülettől való eltávolításukról a testület parancsnoka dönthetett, amelyre általában fegyelmi okok, vagy szolgálati használhatatlanság miatt került. Az újonconak 3 kiképzési ciklusból álló — a lovasoknál egyéves idôtartamú, a gya- 
logosok esetében pedig 7 hónapos - felkészítésen kellett résztvenniük. A kiképzés végén eredményes vizsgát tett újoncok voltak szolgálatba vezényelhetők. ${ }^{9}$

A csendőrség felvételi követelményeinek megfelelő jelentkezők voltak felvételi vizsgára bocsáthatók. A felvételi vizsga az egészségi állapot felmérését biztosító orvosi vizsgálatból és elméleti vizsgából állt. Az elméleti vizsga részét képezte:

- 15 soros - egyszerú szöveg — tollbamondása, a helyesírási készség felmérése céljából;

- legalább 25 soros fogalmazvány készítése, szóban ismertetett helyzet alapján;

- néhány soros szöveg fennhangon való olvasása;

- a négy számtani alapmüvelet egész számokkal való megvalósítása.

A vizsgázóknak 2 óra állt a rendelkezésükre az írásos feladatok teljesítésére és fél óra a számtani müveletek elvégzésére.

A testi- vagy beszédhibás jelentkezőt a testület kötelékébe nem lehetett felvenni. A felvételizők teljesítményét a felvételiztetők pontozták. A csendőrségi szolgálatra alkalmasnak talált jelölteket három csoportba sorolták.

Az első csoportba helyezték azokat, akik a maximális 100 pontból 85 vagy annál több pontot kaptak.

A második csoportba kerültek a 75 és 85 pont között teljesítők.

A harmadik csoportba kerültek, akik 50 és 74 pont közötti teljesítményt nyújtottak.

A csoportokon belüli sorrendet a pontszám döntötte el, kivéve a harcos állományban szolgálatot teljesített katonákat, akiket a csoport élére kellett helyezni.

Az első csoportba tartozó jelentkezőket azonnal felvették, a második és harmadik csoportba tartozókat pedig akkor, ha még mindig volt létszámhiány. A belga csendőrök nem teljesíthettek szolgálatot ott, ahol ők vagy feleségük született, illetve a családjuk a szolgálat megkezdése elött élt. ${ }^{10}$

A belga csendőrség tiszti karával szembeni képesítési követelmény a katonatisztképző oktatási intézmény eredményes elvégzése volt. A csendőrökre pedig a katonákra érvényes 
nyugdíjszabályok vonatkoztak. E tekintetben is azonos helyzetben volt a Belga Nemzeti Csendőrség és a Magyar Királyi Csendörség. ${ }^{11}$

A belga csendőrség legénységének a továbbképzésére a beosztási helyükön került sor, hasonlóan a Magyar Királyi Csendőrség gyakorlatához. A Belga Nemzeti Csendőrség őrsein is szigorú napirend szerint zajlott az élet, amelyben helyet kapott a gyakorlatorientált továbbképzés. Ez alapvetően nem új ismeretek elsajátítását, hanem a meglévő ismeretek alkalmazási képességének fejlesztését, illetve a más kialakult készségek gyakorlását jelentette.

A belga csendörség feladatköre sokoldalú volt. A teljesség igénye nélkül:

- Biztosítania kellett a közterületeken a szabd mozgást, a közúti forgalom szabályai ellen vétőkkel szemben fel kellett lépnie.

- Figyelemmel kellett kísérnie a nagyobb létszámú csoportosulásokat. Intézkednie kellett a csavargókkal, gyanús személyekkel, koldusokkal szemben. A fegyveres csoportosulásokat erőszakkal is szét kellett oszlatnia.

- Segítenie kellett a hatóságok tevékenységét a törvényi kereteken belül. A hivatalos személyeket tisztségük gyakorlásában megzavarókat el kellett fogni és a hivatalos személyeket meg kellett védeni.

- El kellett fogni a katonaszökevényeket, illetve gondoskodnia kellett arról, hogy az alakulatoktól lemaradt, illetve a szabadságolt katonák visszatérjenek alakulatukhoz.

- Ellenőriznie kellett az országba utazó idegeneket a határon történő be- és kilépés alkalmával, valamint az uticéljuk helyszínén is.

- Meg kellett akadályozni a köz- és magánvagyonnak, a természeti értékeknek a rongálását, a rongálókkal fel kellett lépni és a rongálási eszközöket elkobozni.

A testület feladatköre nyilvánvalóan alapvetően közrendvédelem természetü volt. A Belga Nemzeti Csendőrség személyi állománya tagjainak el kellett fognia a vétkeseket, illetve fel kellett derítenie azokat, velük szemben azonban már az el- 
járást nem a csendőrök folytatták le, hanem az illetékes hatóság. Ebből fakadóan a testület senkit sem tarthatott fogva, hanem az elfogást követően — a jegyzőkönyv felvétele után haladéktalanul át kellett adni az érintett személyeket a hatóságoknak. $^{12}$

A Belga Királyságban gondosan szabályozták az alapvető szabadságjogokat érintő rendfenntartói tevékenységeket. Mivel a lakóépületeket az abban lakók sérthetetlen menedékhelyének tekintették („Az én házam az én váram”) a csendőrök oda éjjel kizárólag tüzvész, árvíz, vagy segélykiáltás esetében léphettek be. Házkutatást, vagy elfogást - érvényes engedély birtokában is — magánlakásokban kizárólag nappal valósíthattak meg. Az épületet éjjel körülzárhatták ugyan, azonban oda csak nappal léphettek be. ${ }^{13}$

A Belga Nemzeti Csendőrség tiszti kara alapvetően irányítási tevékenységet látott el, a konkrét intézkedésekben nem vett részt. A testület életét meghatározták a különböző szemlék, amelyeket a tiszti kar tagjai hajtottak végre. Az eltérő szintü beosztásokat betöltők tisztek eltérő tartalmú szemlék megvalósítására voltak kötelezettek. A szemlékre rendszeresen került sor oly módon, hogy a magasabb beosztású tisztek ritkábban, az alacsonyabb beosztású tisztek pedig gyakrabban szemléztek. A szem-lékről jegyzőkönyvek készültek, amelyek - a szolgálati eredményességgel, vagy eredménytelenséggel - az alegységek minősítésének az alapját képezték.

A belga csendőr testület müködésének fontos része volt a jelentési kötelezettség is. A rendkívüli eseteket mindenkinek 24 órán belül kellett jelentenie a szolgálati elöljárójának, aki azt köteles volt azonnal továbbítani. Egyébként pedig — a vezetési szinttől függően meghatározták hogy milyen szintü parancsnok jelent a hét mely napján szolgálati elöljárójának. ${ }^{14}$

Valamennyi parancsnoknak nyilván kellett tartani a testület müködtetésére vonatkozó intenciókat, illetve a szolgálati elöljáróinak az utasításait, továbbá a saját parancsait. Az őrsök személyi állományával ezeket a szabályzókat ismertetni kellett, az elsajátításukról pedig a szemlék alkalmával a tiszteknek meg kellett győződniük. Valamennyi parancsnokságnak kétféle okmányt kellett vezetnie. A parancsok, utasítások, in- 
tézkedések stb. számára a „parancskönyv”-et a hivatalos levelezésről pedig a „levelezési könyv”-et kellett nyilvántartás jelleggel vezetni. Az örsök számára elöírták az úgynevezett szolgálati könyv vezetését is, amelyben azt tüntették fel, hogy ki, mikor és hol teljesített szolgálatot, továbbá azt is hogy a szolgálat során mi történt. Emellett a századosok az alárendeltjeik szabadságát és eltávozását is nyilvántartották, továbbá a beosztottaikról fegyelmi lajstromot vezettek, amelyben nyilvántartották az elismerésre méltó tevékenységeket és a helytelen tetteket, továbbá a fenyítéseket is.

A csendőrség köteles volt a közigazgatás megfelelő ágának területileg illetékes vezetöjét - a testületen belül azonos szintü csendőr parancsnok által — értesíteni minden eseményről, jelenségröl stb. amely az adott közigazgatási hatóságra tartozott. Ezen értesítési kötelezettség kölcsönös volt. ${ }^{15}$

A belga hatóságok területi szervezetei a Balga Nemzeti Csendőrség területileg illetékes alakulataihoz úgynevezett megkereséseket küldhettek, amelyekben a csendőrséget feladatok teljesítésére kérték fel. Ezeket a megkereséseket a tiszti kar tagjai véleményezték abból a szempontból, hogy az azokban foglaltak harmonizálnak-é a vonatkozó törvényekben foglaltakkal. Az ily módon jóváhagyott megkereséseket pedig továbbították az őrsöknek. Az őrsök tehát már az ellenőrzött tartalmú, a tisztjeik által jóváhagyott megkereséseket kapták meg, melyet kötelesek voltak végrehajtani, hiszen azok egyben a feletteseik parancsai is voltak. A csendörök ugyanis - a tisztjeiken kívül mástól nem — csak a szolgálati elöljáróiktól fogadhattak el utasítást. A belga csendöröket sem a közigazgatás tisztviselöi, sem pedig a belga hadsereg tisztjei nem utasíthatták, bármilyen magas rangban, bármilyen magas beosztást töltöttek be. ${ }^{16}$

A fegyelemsértések jellegét utólag is jól meg lehet határozni annak alapján, hogy milyen esetekre írt elö a testület szabályzata fegyelmi felelősségre vonást. A belga csendőrségnél minden fenyítés ellen panaszt tehetett a megfenyített a fenyítést kiszabó parancsnok közvetlen szolgálati elöljárójánál, ez azonban a fenyítést illetően nem volt halasztó hatályú. 
A fenyítés lényegében szobafogságot, illetve minősített esetben magánfogságot jelentett, amikor a fenyített a fenyítés időszakában szolgálatot sem láthatott el, illetve az örs körüli gazdasági munkálatokban sem vehetett részt. A fenyítés időtartama 15 napnál nem lehetett hosszabb. A belga csendőrök fenyíthetök voltak, ha:

- állomáshelyüket eltávozási engedély nélkül elhagyták, illetve a meghatározott időre nem tértek vissza, továbbá ha az elhelyezési körletükön kívül éjszakáztak;

- a rájuk bízott felszerelési tárgyak, illetve szolgálati állatok gondozását elhanyagolták;

- lerészegedtek, adóságot csináltak, illetlenül viselkedtek;

- a rájuk bízott szolgálati titkokat kifecsegték, vagy más módon illetéktelenek számára hozzáférhetővé tették;

- szolgálatukat hanyagul teljesítették, a kapott parancsokat késedelmesen hajtották végre;

- a kötelező foglalkozásokon nem jelentek meg;

- a szabályzatokban rögzített rendet és fegyelmet bármilyen módon megszegték illetve megzavarták.

Visszaesők estében a kiszabott fenyítés időtartama kétszerezhető volt.

Fenyítés kizárólag alapos kivizsgálás nyomán volt kiszabható.

Amennyiben a fenyítést kiszabó elöljáró úgy ítélte meg a helyzetet, hogy a hiba olyan jellegü, amely felelősségre vonásának példamutatónak kell lennie, ezért azt célszerü nyilvánossá tenni, így a fenyítést a legközelebbi őrsszemlén hirdették ki.

Abban az esetben, ha a csendör olyan cselekményt követett el amely a büntető törvényekben rögzített tényállások valamelyikét kimerítette, akkor az illetékes katonai, vagy polgári bíróságnak kellett átadni.

Nem a fenyítés kategóriájába tarozott ugyan, azonban mégis a rend fenntartásának a részét alkotta hogy a parancsnokoknak kötelező volt minden nő számára megtiltani a laktanyában való lakást, ha nem volt valamely csendör felesége, továbbá ki kellett tiltani a laktanya területéről azon nőket, akik illetlenül, kihívó módon öltözködtek és viselkedtek. ${ }^{17}$

Nem lehet nem észrevenni milyen markáns hasonlóság 
volt a korabeli Magyar Királyi Csendőrség és a Belga Nemzeti Csendőrség között. A két testület szervezeti felépítése, a szolgálati feladatkörük, a legénységi és a tiszti kar teendőinek a jellege, az egy före jutó terület mérete tekintetében — néhány apróbb kivételtől eltekintve - szinte azonos volt a két testület. Természetesen az alapok is megegyeztek, hiszen mindkét szervezet katonailag szervezett fegyveres örtestület volt. A legfontosabb különbség minden bizonnyal a belga testület 22,33 \%át alkotó 1272 főnyi mobil csendőrség léte alkotta, mivel a Magyar Királyi Csendőrség személyi állományából a karhatalmi feladatok ellátására ekkor még szakalegységeket nem különítettek ki.

Ugyancsak szembe ötlö, hogy a belga nemzet viszonylag csekély képzettségü tagjaiból milyen hasznos - az egész ország javát szolgáló — testületet lehetett múködtetni a katonai vezetési elvek és módszerek céltudatos adaptálásával.

$\mathrm{Az}$ is nyilvánvaló, hogy azon elvek és elvárások, amelyek mentén zajlott a testület mindennapi tevékenysége, minden bizonnyal pozitív hatást gyakoroltak a személyi állomány mentalitására. A belga csendőrség léte — amelynek a müködését a szakirodalom nem népnyúzó szervezetként tárgyalja — eklatáns cáfolatát adja annak a tévhitnek, mely szerint a katonailag szervezett őrtestületek kizárólag negatív szerepet játszhatnak a nemzeti rendvédelmi modellekben, mivel a parancsnoklási rendszerükből fakadóan a törvények betartása és betartatása számukra indifferens. Ez a tévhit azon a sajátos rosszindulatú feltételezésen nyugszik, hogy maga az államhatalom, illetve annak gyakorlói nemzetellenesek és törvénytelenségekre törekednek. Ez a kibicsaklott okfejtés azonban zátonyra fut, amikor szembesül azzal a ténnyel, ahogyan a csendőrségnél a katonai viszonyrendszer nyújtotta lehetőségeket hasznosították a hatályos jogrendszer érdekében. 
Jegyzetek:

1 ÖRY: 75-77.p.

${ }^{2}$ PARÁDI: A katonailag szervezett örtestület és a polgári örtestület. 77-84.p.

${ }^{3}$ TiHANYi: I.rész. 470.p.

${ }^{4}$ PARÁDI: A Magyar Királyi Csendörség. Az első magyar polgári, központositott közbiztonsági ốrtestület 1881-1945. 65-66.p.

${ }^{5}$ TiHANYI: I.rész. op.cit. 471.p.

${ }^{6}$ PARÁDI: A Magyar Királyi Csendőrség szervezete. 81-89.p. ; PARÁDI: Rendvédelem-karhatalom 1867-1945. 112-122.p.

${ }^{7}$ Tinanyi: I.rész. op.cit. 472.p.

${ }^{8}$ Loc.cit. VII.rész. 692.p.

${ }^{9}$ Loc.cit. VII.rész. 693.p.

${ }^{10}$ Loc.cit. VII.rész.

11 Loc.cit. II.rész. 510.p. ; PARÁDI: Rendvédelmünk képzési és képesítési rendszere 1867-1945. 91-92.p. ; Idem: A csendőrtisztképzés és a fizetési osztályokba sorolt állami alkalmazottak szakvizsgarendszere. 101103.p. ; Idem: A magyar rendvédelem személyi állományának szociális viszonyai 1867-1945. 58-61.p. ; Idem: A polgári magyar állam rendvédelmi testületeinek humán viszonyai 1867-1945. 93-113.p.

${ }^{12}$ Tihanyi: I.rész. op.cit. 471-472.p.

${ }^{13}$ Október 1-je és március 31-e között éjszakának minősült az este 10 és a reggel 6 óra közötti idő, április 1-je és szeptember 30-a között pedig éjszakának minősült az este 9 és a reggel 4 óra közötti idő.

Loc.cit. I.rész. 472.p.

${ }^{14}$ Loc.cit. III.rész. 543-544.p.

${ }^{15}$ Loc.cit. 544-545.p.

${ }^{16}$ Loc.cit. IV.rész. 580-581.p.

${ }^{17}$ Loc.cit. VI.rész. 658-659.p.

Jegyzetekben alkalmazott röviditések:

\section{MONOGRÁFIÁK ÉS KISMONOGRÁFIÁK ÉS HASONLÓ JELLE- GÜ KÖTETEK}

PARÁDI: A Magyar

Királyi Csendörség. Az elsö ma-gyar polgári, központosí-tott

közbiztonsági örtestü-let 1881-1945.
PARÁdI József: A Magyar Királyi Csendörség. Az elsö magyar polgári, központositott közbiztonsági örtestület 1881-1945. Budapest, 2012, Szemere Bertalan Magyar Rendvédelem-történeti Tudományos Társaság. 281 p. HU-ISBN 978963084794 0. /A magyar rendvédelem-történet öröksége, 2./ HU-ISSN 2062-8447. 


\section{TANULMÁNYOK}

ÖRY

PARÁDI: Rendvédelmünk képzési és képesítési rendszere 1867-1945.

PARÁDI: A csendörtisztkép- - zés és a fizetési osztályokba sorolt állami alkalmazottak szakvizsgarendszere.
ÖRY Károly: A Maréchaussée-tól a Gendarmerie Nationale-ig. A Francia Csendörség történeti előzményei. Rendvédelem-történeti Füzetek (Acta Historiae Praesidii Ordinis), VII.évf. (1997) 8.sz. 75-77.p. HUISSN 1216-6774. A tanulmány korábbi változata 1996. október 29-én Budapesten hangzott el a Szemere Bertalan Magyar Rendvédelem-történeti Tudományos Társaság által szervezett rendvédelem-történeti tudományos konferencia-sorozatnak , $A \quad n a-$ póleoni közbiztonsági örtestület útja Párizstól - Itálián és Ausztrián keresztül - Budapestig" címü VIII. konferenciáán. A publikált tanulmány az előadás javított, bővített és átdolgozott változata.

PARÁDI József: Rendvédelmünk képzé-si és képesítési rendszere 1867-1945. Rendvédelem-történeti Füzetek (Acta Historiae Praesidii Ordinis), XIII.évf. (2007) 16.sz. 90-93.p. HU-ISSN 1216-6774. A tanulmány korábbi változata 2002. november 12én Budapesten hangzott el a Szemere Bertalan Magyar Rendvédelem-történeti Tudományos Társaság által szervezett rendvédelem-történeti tudományos konferencia-sorozatnak „A rendvédelmi szakképzés története" címü XVI. konferenciáján. A publikált tanulmány az előadás javított, bővített és átdolgozott változata.

PARÁDI József: A csendőrtisztképzés és a fizetési osztályokba sorolt állami alkalmazottak szakvizsgarendszere. Rendvédelem-történeti Füzetek (Acta Historiae Praesidii Ordini), XIII.évf. (2007) 16.sz. 100104.p. HU-ISSN 1216-6774. A tanulmány korábbi változata 2002. november 12-én hangzott el a Szemere Bertalan Magyar Rendvédelem-történeti Tudományos Társaság által szervezett rendvédelem-történeti tudományos konferenciasorozatnak „A rendvédelmi szakképzés története" címü XVI. konferenciáján. A publikált tanulmány az előadás javított, bővített és átdolgozott változata. 
PARÁDI: A magyar rendvédelem személyi állományának szociális viszonyai 1867-1945.

PARÁDI: A polgári magyar állam rendvédelmi testületeinek humán viszonyai 1867-1945.
PARÁDI: A Magyar Királyi Csendőrség szervezete.
PARÁDI József: A magyar rendvédelem személyi állományának szociális viszonyai 1867-1945. Rendvédelem-történeti Füzetek (Acta Historiae Praesidii Ordinis), XV.évf. (2008) 17.sz. 57-64.p. HU-ISSN 12166774. A tanulmány korábbi változata 2003. november 11-én Budapesten hangzott el a Szemere Bertalan Magyar Rendvédelemtörténeti Tudományos Társaság által szervezett rendvédelem-történeti tudományos konferenciasorozatnak a „A rendvédelem humán viszonyai" címü XVII. konferenciáján. A publikált tanulmány az előadás javított, bővített és átdolgozott változata.

PARÁDI József: A polgári magyar állam rendvédelmi testületeinek humán viszonyai 1867-1945. Rendvédelem-történeti Füzetek (Acta Historiae Praesidii Ordinis), XIX. évf. (2010) 22. sz. 92-114.p. A tanulmány korábbi változata 2008. október 10-én Budapesten hangzott el, a Szemere Bertalan Magyar Rendvédelem-történeti Tudományos Társaság által szervezett rendvédelem-történeti tudományos konferenciasorozatnak „Másfél évszázad rendszerváltozásainak hatásai a nemzeti rendvédelmünkre" címü XXII. konferenciáján. A publikált tanulmány az előadás javított, bővített és átdolgozott változata.

PARÁDI József: A Magyar Királyi Csendőrség szervezete. Rendvédelem-történeti Füzetek (Acta Historiae Praesidii Ordinis), XXI.évf. (2011) 24.sz. 80-90.p. A tanulmány korábbi változata 2009 december 3-án Budapesten hangzott el, a Szemere Bertalan Magyar Rendvédelem-történeti Tudományos Társaság által szervezett rendvédelem-történeti tudományos konferencia-sorozatnak ,, Csendörség Ausztria-Magyarországon, illetve Ausztriában és Magyarországon 1849-2005” címü XXIV. konferenciáján. A publikált tanulmány az előadás javított, bővített és átdolgozott változata. 
PARÁDI: Rendvédelem-kar- hatalom 1867-1945.

PARÁDI: A katonailag szer- - vezett örtestület és a polgári őrtestület.
PARÁDI József: Rendvédelem-karhatalom 1867-1945. Rendvédelem-történeti Füzetek (Acta Historiae Praesidii Ordinis), XX.évf. (2011) 24.sz. 111-123.p. HUISSN 1216-6774. A tanulmány korábbi változata 2009.október 9-én, Budapesten hangzott el a Szemere Bertalan Magyar Rendvédelem-történeti Tudományos Társaság által szervezett rendvédelem-történeti tudományos konferenciasorozatnak a „A kiegyezéstöl az ezredfordulóig felszámolt országos hatáskörü magyar rendvédelmi testületek." címü XXIII. konferenciáján. A publikált tanulmány az előadás javított, bővített és átdolgozott változata.

PARÁDI József: A katonailag szervezett örtestület és a polgári örtestület. Rendvédelem-történeti Füzetek (Acta Historiae Praesidii Ordinis), XXV.évf. (2015) 43-4445-46.sz. 77-84.p. HU-ISSN 1216-6774.

\section{CIKKEK}

TIHANYI
TiHANyi Ferenc: A belga csendőrség. Csendörségi Lapok, XVII.évf. (1927) 15.sz. 470-473.p. I.rész.

Csendörségi Lapok,

XVII.évf. (1927) 16.sz. 509-511.p. II.rész.

Csendörségi Lapok,

XVII.évf. (1927) 17.sz. 543-545.p. III.rész. Csendörségi Lapok,

XVII.évf. (1927) 18.sz. 578-581.p. IV.rész.

Csendörségi Lapok,

XVII.évf. (1927) 19.sz. 620-621.p. V.rész.

Csendörségi Lapok,

XVII.évf. (1927) 20.sz. 658-660.p. VI.rész.

Csendörségi Lapok,

XVII.évf. (1927) 21.sz. 692-693.p. VII.rész. 